\title{
Gender Differences in Response to Cold Pressor Test in the Age Group of 18-30 Years
}

\author{
Hasana Fatima $^{1}$, R. Anitha ${ }^{2}$, Mudassir Mirza ${ }^{3}$ \\ ${ }^{1}$ Postgraduate Student, ${ }^{2}$ Professor, ${ }^{3}$ Assistant Professor, Upgraded Department of Physiology, \\ Osmania Medical College, Hyderabad, Telangana State
}

\begin{abstract}
Introduction: The Cold Pressor Test (CPT) was first introduced by Hines and Brown in 1932. It was designed to measure the reactivity of the blood vessels to a standard stimulus ${ }^{2}$. Cold Pressor Test is an established challenge test of sympathetic vascular regulation. Sympathetic nervous system activity varies in males and females.
\end{abstract}

Aim: To study the response of Cold Pressor Test on blood pressure in normal healthy young adult males and females.

Materials and Method: After Institutional ethics committee approval, a total of 104 subjects in the age group of 18-30 years were recruited with informed consent for the study, after considering inclusion and exclusion criteria. Subjects were explained about the test procedure. Basal blood pressure (pre-test BP) was recorded after $20 \mathrm{~min}$. of rest. Systolic and diastolic blood pressure was measured in $\mathrm{mmHg}$ (pre-test). Subject was asked to dip left hand till the wrist in cold water $\left(4^{0}-8^{0} \mathrm{C}\right)$ for $1 \mathrm{~min}$. (minute).Blood pressure was recorded from right arm during the test, 1 minute, 2 minutes, 3 minutes and 4 minutes after the test.

Result: Basal BP was significantly higher in males than in females. Systolic BP(SBP) response, Diastolic $\mathrm{BP}$ response (DBP) to CPT were statistically higher in males compared to females.

Conclusions: The gender variations are seen due to differences in the sympathetic nervous system activity and due to the effect of sex hormones. Males are more prone to develop hypertension and other cardiovascular disorders when compared to females due to higher sympathetic activity.

Keywords: Cold Pressor test, sympathetic nervous system, males, females.

\section{Introduction}

The subjects prone to develop hypertension in later life have a period of underlying sympathetic overactivity ${ }^{1}$. Increased sympathetic and decreased parasympathetic activities in young adults alters sympathovagal balance,

\footnotetext{
Corresponding Author:

Dr. Hasana Fatima

Postgraduate Student, Upgraded Department of

Physiology, Osmania Medical College, Hyderabad,

Telangana State

e-mail: izznafatima@yahoo.in
}

which could be the major mechanism in causation of pre hypertension ${ }^{3}$. Sustained sympathetic overactivity has been reported as among the primary mechanisms for genesis of essential hypertension ${ }^{2}$. The subjects at risk of developing hypertension can be identified by performing the CPT.

The Cold Pressor Test (CPT) was first introduced by Hines and Brown in 1932. It was designed to measure the reactivity of the blood vessels to a standard stimulus ${ }^{2}$. (CPT) is an established challenge test of autonomic vascular regulation. This study aims to study the gender variation in response to CPT, giving insight into level of sympathetic activity, and subsequent risk of developing hypertension in future and other cardiovascular disorders. 


\section{Materials and Method}

104 Subjects 18-30 years, studying in Osmania Medical College.

\section{Inclusion Criteria:}

Healthy Young adult offspring of

1. Normotensive parents.

2. Either one or both parents can be hypertensive.

\section{Exclusion Criteria:}

Subject with history of

1. Hypertension

2. Diabetes Mellitus

3. Cardiovascular disorders

4. Neuropathy

5. Addictions to tobacco/alcohol.

\section{Materials and Method}

Mercury Sphygmomanometer, Stethoscope, Thermometer, Timer, Ice water at $4^{\circ}-8^{\circ} \mathrm{C}$, Stadiometer, Weighing machine.

\section{Instructions:}

Subjects were asked

1. Not to have caffeine rich drinksat least 2-3 hour prior to test.

2. Not to perform Valsalva manoeuvre \& isometric contraction during the test.

Procedure: After Institutional ethics committee approval, with informed consent subjects were recruited for the study. Details regarding the health status, past medical history, past cardiac surgeries, family history of hypertension (in parents), addictions were obtained. Subjects were explained about the test procedure. Basal blood pressure (pre-test BP) was recorded after 20 minutes of rest. SBP \& DBP was measured in $\mathrm{mmHg}$ (pre-test). Subject was asked to dip left hand till the wrist in cold water $\left(4^{\circ}-8^{\circ} \mathrm{C}\right)$ for 1 minute. Blood pressure was recorded from right arm during test, 1 minute, 2 minute, 3 minute \& 4 minute after the test.

Statistical analysis: Unpaired $t$ test was used to find the significance between various parameters. $p$ value $<0.05$ was considered as statistically significant $(*)$.

\section{Observation and Results:}

Table 1: Characteristics of male and female subjects

\begin{tabular}{|l|c|c|c|}
\hline Parameter & Male & Female & p value \\
\hline Number & 45 & 59 & - \\
\hline Age (years) & $19.78 \pm 2.89$ & $20.50 \pm 3.97$ & 0.294 \\
\hline Height (meters) & $1.671 \pm 0.71$ & $1.58 \pm 0.091$ & $0.001 *$ \\
\hline Weight $(\mathrm{kg})$ & $59.89 \pm 10.71$ & $56.93 \pm 11.54$ & 0.185 \\
\hline BMI $\left(\mathrm{kg} / \mathrm{m}^{2}\right)$ & $24.06 \pm 4.67$ & $25.90 \pm 4.20$ & 0.037 \\
\hline
\end{tabular}

Table 2: Comparison of Basal Blood Pressure (mmHg) between males and females

\begin{tabular}{|l|c|c|c|}
\hline Parameter & Male & Female & p value \\
\hline Basal SBP & $110 \pm 8.52$ & $101.70 \pm 9.86$ & $0.001^{*}$ \\
\hline Basal DBP & $72.67 \pm 5.94$ & $69.29 \pm 7.22$ & $0.01 *$ \\
\hline
\end{tabular}

Table 3: Comparison of Systolic Blood Pressure response to CPT (mmHg) between males and females

\begin{tabular}{|l|c|c|c|}
\hline Parameter & Male & Female & p value \\
\hline Basal SBP & $110 \pm 8.52$ & $101.70 \pm 9.86$ & $0.001 *$ \\
\hline During test & $127.42 \pm 9.48$ & $119.12 \pm 10.76$ & $0.001 *$ \\
\hline 1 min after test & $115.91 \pm 11.26$ & $107.56 \pm 11.79$ & $0.001 *$ \\
\hline
\end{tabular}




\begin{tabular}{|l|c|c|c|}
\hline Parameter & Male & Female & p value \\
\hline 2min after test & $109.20 \pm 9.12$ & $102.10 \pm 10.35$ & $0.001 *$ \\
\hline 3 min after test & $108.09 \pm 8.92$ & $100.91 \pm 9.53$ & $0.001 *$ \\
\hline 4 min after test & $107.46 \pm 9.18$ & $99.93 \pm 9.07$ & $0.001 *$ \\
\hline Maximum SBP & $127.42 \pm 9.48$ & $119.12 \pm 10.76$ & $0.001 *$ \\
\hline Change in SBP & $16.18 \pm 7.45$ & $16.91 \pm 8.19$ & 0.637 \\
\hline
\end{tabular}

Table 4: Comparison between Diastolic Blood Pressure (mmHg) response to CPT between males and females

\begin{tabular}{|l|c|c|c|}
\hline Parameter & Male & Female & p value \\
\hline Basal DBP & $72.67 \pm 5.94$ & $69.29 \pm 7.22$ & $0.01^{*}$ \\
\hline During test & $86.98 \pm 10.50$ & $69.29 \pm 7.22$ & $0.01^{*}$ \\
\hline 1 min after test & $77.87 \pm 8.81$ & $72.10 \pm 9.67$ & $0.002^{*}$ \\
\hline 2min after test & $73.91 \pm 6.22$ & $69.53 \pm 8.41$ & $0.005^{*}$ \\
\hline 3 min after test & $73.02 \pm 6.61$ & $68.47 \pm 7.61$ & $0.002^{*}$ \\
\hline 4 min after test & $72.89 \pm 6.61$ & $68.03 \pm 7.40$ & $0.001^{*}$ \\
\hline Maximum DBP & $86.76 \pm 10.76$ & $81.22 \pm 9.04$ & $0.005^{*}$ \\
\hline Change in DBP & $13.73 \pm 8.47$ & $11.18 \pm 6.50$ & 0.086 \\
\hline
\end{tabular}

\section{Discussion}

Males had higher basal SBP $(110 \pm 8.52 \mathrm{mmHg}) \&$ higher DBP $(72.67 \pm 5.94 \mathrm{mmHg})$ compared to basal SBP $(101.70 \pm 9.86 \mathrm{mmHg}) \&$ basal DBP $(69.29 \pm 7.22 \mathrm{mmHg})$ in females, which was statistically significant $(\mathrm{p}=0.001)$. This is in accordance with study done by Weiinber \& colleagues ${ }^{4}$, Khoury et $\mathrm{al}^{5}$, a meta- analysis study by Staessen et $\mathrm{al}^{6}$, The third National Health \& Nutrition Evaluation Survey ${ }^{7}$ (NHANESIII).

BP recordings during CPT \& sequentially every minute thereafter up to 4 minutes, reveal statistically significant higher values in males compared to females. The higher SBP in males $(127.42 \pm 9.48 \mathrm{mmHg})$ during CPT when compared to females $(119.12 \pm 10.76 \mathrm{mmHg})$ correlating with Srivastava et $\mathrm{al}^{8}(\mathrm{P}=0.001)$.

BP measurement continued after the removal of hand from the cold water in order to detect delayed pressor effect and duration of elevated blood pressure.

The SBP values 1 minute after the test were higher in males $(115.91 \pm 11.26 \mathrm{mmHg})$ than in females $(107.56 \pm 11.79 \mathrm{mmHg})$. The SBP values 2 minutes, 3 minutes, 4 minutes after test were significantly higher in males than in females.
The maximum SBP attained in males was higher $(127.42 \pm 9.48 \mathrm{mmHg})$ than in females $(119.12 \pm 10.76 \mathrm{mmHg}) \&$ the $p$ value was statistically significant $(p=0.001)$. The change in SBP (Maximum SBP minus Basal SBP) was higher in females $(16.91 \pm 8.19 \mathrm{mmHg})$ than in males $(16.18 \pm 7.45 \mathrm{mmHg})$ and was not statistically significant $(p=0.637)$. The change in SBP was higher in females correlating with Srivastava et $\mathrm{al}^{8}$.

The DBP response to CPT during test was higher in males $(86.98 \pm 10.50 \mathrm{mmHg})$ than in females $(69.29 \pm 7.22$ $\mathrm{mmHg}) \&$ the values were statistically significant $(p=0.001)$ correlating with Srivastava et $\mathrm{al}^{8}$. Males had higher DBP values 1 minute, 2 minutes, 3 minutes \& 4 minutes after the test than females. Maximum DBP attained was higher in males than in females. The change in DBP was more in males $(13.73 \pm 8.47 \mathrm{mmHg})$ than in females $(11.18 \pm 6.50 \mathrm{mmHg})$ in contradiction to Srivastava et al. ${ }^{8}$ with a higher change in DBP in females than in males.

Mechanism of CPT induced increase in $\mathrm{BP}^{9}$ : When the hand is immersed in cold water $\left(4^{\circ}-8^{\circ} \mathrm{C}\right)$, the A \& $\mathrm{C}$ fibres are activated in response to pain, temperature sensation. These fibres ascend contralaterally as 
anterolateral system which includes Spinothalamic, Spino-reticular \& Spino-mesencephalic tracts. The nociceptive specific neurons ascend in the lateral mesencephalon, while the thermoreceptive specific neurons project to Dorsomedial part of ventro posteromedial nucleus of Thalamus. The ascending fibres of spinoreticular tract project to medullary reticular formation, via the Ionotropic Glutamate receptors activate the Rostral Ventrolateral Medullary (RVLM) neurons resulting in increased sympathetic nervous activity leading to increase in blood pressure, heart rate, total vascular resistance, muscle sympathetic activity $^{10,11,12}$, decrease inforearm blood flow ${ }^{13}$. Thus, CPT increases the sympathetic nervous system activity to increase the BP which depends on the sympathetic tone.

\section{In the present study, males had higher:}

1. Basal SBP \& DBP

2. SBP \& DBP during the test

3. SBP \& DBP 1 minute, 2 minutes, 3 minutes \& 4 minutes after the test.

Gender variations to CPT is due to androgens, estrogen, progesterone.

Androgensplays a crucial role in gender differences in blood pressure regulation. The probable mechanisms by which androgens lead to increased blood pressure are: Androgens lead to increased formation of Angiotensin II, which increasesoxidative stress leading to production of superoxide, quenching of Nitric Oxide, and also reducethe renal vascular response to vasodilators, including residual Nitric Oxide(NO). Androgens also cause production of $\mathrm{F} 2$-isoprostanes which potentiate the effect of Ang II as avasoconstrictor, and alsostimulate endothelin-1 production to increase blood pressure further. ${ }^{14}$

Estrogens and their receptors play a crucial role in endothelium-dependent maintenance of vascular tone ${ }^{15-17}$. Estrogenscause relaxation via endotheliumderived hyperpolarizing factor (EDHF), by inducing vasodilator prostanoids (PGE2, PGI2), and by inhibiting endothelin-1 production ${ }^{18}$. Endothelial progenitor cells (EPCs) also play a crucial role in vascular response. Fertile females havehigher levels of EPC than men. Intrinsic differences within the endothelial cells contribute to differences between men and women. Other factors that modulate autonomic cardiac activity, may influence sex differences, such as inflammation, increased pain sensitivity to cold, and psychological disorders (e.g. depression). Healthy females have a lower central sympathetic neural output to periphery and a lower sympathetic vasoconstrictor drive when compared to healthy men. ${ }^{19}$ Studies done at molecular level indicate that centralactions of estrogens include facilitation of cholinergic transmission and activating the synthesis of a vital rate limiting enzyme choline acetyltransferase, involved in the formation of acetylcholine formation, and also have a role in sympathetic outflow inhibititon ${ }^{20,21}$

Estrogen $^{22}$ decreases the production of cyclooxygenase derived products, reactive oxygen species, angiotensin-II \& endothelin-1 which are vasoconstrictor agents. It inhibits smooth muscle cells by activating $\mathrm{K}+$ efflux \& by inhibiting calcium influx through inhibition of L-type $\mathrm{Ca}^{2+}$ channels and decreases myosin light chain phosphorylation and contraction of smooth muscle. Estrogen also inhibits proliferation of vascular smooth muscle cell.

Membrane-impermeant forms of estrogenacts oncell surface estrogen receptors, leading to the activation of mitogen-activated protein kinase (MAPK) and increased cGMP production and nitric oxide (NO) release.

Estrogenacts on the renin-angiotensin system is at the formation of Ang II, at the Ang II receptors level and on Ang II-induced responses ${ }^{22}$. Estrogen increases gene expression and plasma levels of angiotensinogen and antagonizes the AT1 receptor-mediated growthpromoting effects of Ang II in vascular smooth muscle cells. Estrogenacts on the endothelin-1 (ET-1) pathway at different levels: at its formation, at level of the receptors and on ET-1-induced responses.

The luteal phase is associated with a significantly reduced parasympathetic activity. The high progesterone levels during the luteal phase may have an inhibitory role on cardio-vagal activity ${ }^{22-25}$. Studies showed a higher sympathetic activity and a sympathovagal imbalance in luteal phase with an associated increase in parasympathetic activity in follicular phase,showing sympathetic predominancein luteal phase 2629. In physiological doses, progesterone acts as a sympathomimetic agent which induces nor epinephrine release $^{30,31}$

The results corroborates with report by Weitz et al ${ }^{32}$, that the activity of sympathetic nervous system shows 
gender specific differences with lower sympathetic nerve activity to muscle vascular bed in women as compared with men, the difference vanishes after menopause.

Thus, the female sex hormones together cause lower $\mathrm{BP}$ response to CPT in females.

\section{Conclusion}

Males had significantly higher values for - Basal SBP \& DBP, SBP \& DBP values during the test, SBP \& DBP values 1 minute, 2 minutes, 3 minutes \& 4 minutes after test, Maximum SBP \& Maximum DBP than females.

The gender variations are seen due to differences in the sympathetic nervous system activity and due to the effect of sex hormones. Males are more prone to develop hypertension and other cardiovascular disorders when compared to females due to higher sympathetic activity.

The Change in SBP \& change in DBP values between males and females are not statistically significant.

Acknowledgements: My gratitude to Dr. A. Santakumari, Professor \& Head of the Department, Faculty members, Post graduate colleagues \& study population for their cooperation.

\section{Conflict of Interest: None}

\section{Source of Funding: Self}

Ethical Clearance: Institutional ethics committee approved.

\section{References}

1. Biaggioni I, Burnstock G, Low PA, Paton JF, Robertson D, editors. Primer on the autonomic nervous system. Academic Press; 2011.

2. Hines Jr EA, Brown GE. The cold pressor test for measuring the reactibility of the blood pressure: data concerning 571 normal and hypertensive subjects. American heart journal. 1936 Jan 1;11(1):1-9.

3. Raj M. Essential hypertension in adolescents and children: Recent advances in causative mechanisms. Indian journal of endocrinology and metabolism. 2011 Oct;15(Supp14):S367.

4. Wiinberg N, Høegholm A, Christensen HR, Bang LE, Mikkelsen KL, Nielsen PE, Svendsen TL, Kampmann JP, Madsen NH, Bentzon MW. 24-h ambulatory blood pressure in 352 normal Danish subjects, related to age and gender. American journal of hypertension. 1995 Oct 1;8(10):978-86.

5. Khoury S, Yavows SA, O'Brien TK, Sowers JR. Ambulatory blood pressure monitoring in a nonacademicsetting: effects of age and sex. American journal of hypertension. 1992 Sep 1;5(9):616-23.

6. Staessen J, Fagard R, Lijnen P, Thijs L, Van Hoof R, Amery A. Reference values for ambulatory blood pressure: a meta-analysis. J Hypertens. 1990;8(suppl 6):S57-S64.

7. Burt VL, Whelton P, Roccella EJ, Brown C, Cutler JA, Higgins M, Horan MJ, Labarthe D. Prevalence of hypertension in the US adult population: results from the Third National Health and Nutrition Examination Survey, 1988-1991. Hypertension. 1995 Mar;25(3):305-13.

8. Srivastava RD, Kumar MA, Shinghal R, Sahay AP. Influence of age and gender on cold pressor response in Indian population. Indian J PhysiolPharmacol. 2010;54(2):174-8.

9. Nakamura T, Kawabe K, Sapru HN. Cold pressor test in the rat: medullary and spinal pathways and neurotransmitters. American Journal of Physiology-Heart and Circulatory Physiology. 2008 Oct;295(4):H1780-7.

10. Wood DL, Sheps SG, Elveback LR, Schirger A. Cold pressor test as a predictor of hypertension. Hypertension. 1984 May;6(3):301-6.

11. Kasagi F, Akahoshi M, Shimaoka K. Relation between cold pressor test and development of hypertension based on 28-year follow-up. Hypertension. 1995 Jan;25(1):71-6.

12. Silverthorn DU, Michael J. Cold stress and the cold pressor test. Advances in physiology education. 2013 Mar;37(1):93-6.

13. Anthony DM, Hamid HS, Rashmi TM. Autonomic response to cold pressor test in relation to $\mathrm{ABO}$ blood groups. Int Res J Biol Sci. 2013;2(10):30-5.

14. Reckelhoff JF. Gender differences in the regulation of blood pressure. Hypertension. 2001 May;37(5):1199-208.

15. Luksha L, Nisell H, Kublickiene K. The mechanism of EDHF-mediated responses in subcutaneous small arteries from healthy pregnant women. American Journal of Physiology-Regulatory, Integrative and Comparative Physiology. 2004 Jun;286(6):R1102-9. 
16. Huang A, Kaley G. Gender-specific regulation of cardiovascular function: estrogen as key player. Microcirculation. 2004 Jan 1;11(1):9-38.

17. Kublickiene $\mathrm{K}$, Luksha L. Gender and the endothelium. Pharmacol Rep. 2008 Jan 1;60(1):4960 .

18. Vaccarino V, Badimon $\mathrm{L}$, Corti $\mathrm{R}$, de Wit $\mathrm{C}$, Dorobantu M, Hall A, Koller A, Marzilli M, Pries A, Bugiardini R. Ischaemic heart disease in women: are there sex differences in pathophysiology and risk factors? Position paper from the working group on coronary pathophysiology and microcirculation of the European Society of Cardiology. Cardiovascular research. 2011 Apr 1;90(1):9-17.

19. Hogarth AJ, Mackintosh AF, Mary DA. Gender-related differences in the sympathetic vasoconstrictor drive of normal subjects. Clinical Science. 2007 Mar 1;112(6):353-61.

20. Bernardi F, Genazzani AR. The brain: target and source for sex steroid hormones. In Women's health and menopause 1999 (pp. 137-143). Springer, Dordrecht.

21. Eskin BA, Snyder DL, Roberts J, Aloyo VJ. Cardiac norepinephrine release: modulation by ovariectomy and estrogen. Experimental Biology and Medicine. 2003 Feb;228(2):194-9.

22. Tostes RC, Nigro D, Fortes ZB, Carvalho MH. Effects of estrogen on the vascular system. Brazilian Journal of Medical and Biological Research. 2003 Sep;36(9):1143-58.

23. Goldstein DS, Levinson P, Keiser HR. Plasma and urinary catechllamines during the human ovulatory cycle. American journal of obstetrics and gynecology. 1983 Aug 1;146(7):824-9.

24. Sato N, Miyake S, Akatsu JI, Kumashiro M. Power spectral analysis of heart rate variability in healthy young women during the normal menstrual cycle. Psychosomatic medicine. 1995 Jul 1;57(4):331-5.

25. Shetty SB, Pai SR, Nayanatara AK, Shetty B. Comparison of cardiac autonomic activity and BMI in different phases of menstrual cycle using heart rate variability. Int J Basic Med Sci. 2011 Sep;2(4):100-5.

26. Tanaka M, Sato M, Umehara S, Nishikawa T. Influence of menstrual cycle on baroreflex control of heart rate: comparison with male volunteers. American Journal of Physiology-Regulatory, Integrative and Comparative Physiology. 2003 Nov;285(5):R1091-7.

27. Yildirir A, Kabakci G, Akgul E, Tokgozoglu L, Oto A. Effects of menstrual cycle on cardiac autonomic innervation as assessed by heart rate variability. Annals of noninvasive electrocardiology. 2001 Jan; 7(1):60-3.

28. Guasti L, Grimoldi P, Mainardi LT, Petrozzino MR, Piantanida E, Garganico D, Diolisi A, Zanotta D, Bertolini A, Ageno W, Grandi AM. Autonomic function and baroreflex sensitivity during a normal ovulatory cycle in humans. Acta cardiologica. 1999 Aug;54(4):209-13.

29. Chatterjee S, Aditya S, Tibarewala DN. A Comparative Study between Females of PrePubertal and Reproductive age groups to explore how HPG-Axis affects the Autonomic Control over Cardiac Activity. Indian J Biomech. 2009 Mar:2336.

30. Mercuro G, Pitzalis L, Podda A, Zoncu S, Pilia I, Melis GB, Cherchi A. Effects of acute administration of natural progesterone on peripheral vascular responsiveness in healthy postmenopausal women. The American journal of cardiology. 1999 Jul 15;84(2):214-8.

31. Bai X, Li J, Zhou L, Li X. Influence of the menstrual cycle on nonlinear properties of heart rate variability in young women. American Journal of Physiology-Heart and Circulatory Physiology. 2009 Aug;297(2):H765-74.

32. Weitz G, Elam M, Born J, Fehm HL, Dodt C. Postmenopausal estrogen administration suppresses muscle sympathetic nerve activity. The Journal of Clinical Endocrinology \& Metabolism. 2001 Jan 1;86(1):344-8. 